\title{
(Non)Places of Bangalore: Where the East Meets the West in Bharati Mukherjee's Miss New India
}

\begin{abstract}
This essay constitutes an attempt at reading Bharati Mukherjee's 2011 novel, Miss New India, through the prism of spatial locations depicted in it. Unlike many of the texts in the late South Asian American author's oeuvre, which depict migration from the East to the West, Miss New India is located exclusively within South Asia. This notwithstanding, the novel focuses on the impact the West used to and continues to exert on the East. I would like to argue that through her depictions of places and non-places of Bangalore - the novel's primary location-Mukherjee points to the spatial interconnectedness of the East and the West as well as to the temporal interconnectedness of the colonial past and postcolonial, late-capitalist present.
\end{abstract}

Keywords: Bharati Mukherjee, Miss New India, Re-Orientalism, non-places, postcolonialism, New India narratives

Bharati Mukherjee, a recently deceased American author of South Asian descent, functioned as a spokesperson for the first generation of South Asian American writers, despite her own negation of hyphenation and a desire to be perceived simply as an American author, sentiments expressed in her essay "Beyond Multiculturalism: Surviving the Nineties." Mukherjee was moving in her literary oeuvre back and forth between America and India, oftentimes juxtaposing the two locations in her narratives of immigration. The binary construction of space - the depiction of the East as the opposite of the West - has in fact been the reason why Mukherjee's texts - and texts by other South Asian American authors, for that matter-have been criticized by scholars for perpetuating the belief in the existence of fossilized, essentialized differences between the East and the West. Such a positioning of the East and the West as binary opposites is nothing new, of course. It was already in the 1970s that in his seminal study Orientalism Edward Said critiqued such a binary way of thinking and defined Orientalism as a "corporate institution for dealing with the Orient-dealing with it by making statements about it, authorizing views of it, describing it, by teaching it, settling it, ruling over it" (3). He concluded that "in short Orientalism [is] a Western style for dominating, restructuring, and having authority over the Orient" (3), claiming that "[t]he relationship between Occident and Orient is a relationship of power, of domination, of varying degrees of a complex hegemony" (5). Even though Said's study concentrated mostly on the unequal relationship between the West and the Middle East, his theorization of the East/West dichotomy seems to apply as well to the relationship between the West and the Indian Subcontinent. Several decades after Said's book was published, already in the twenty-first century, Lisa Lau coined the term "Re-Orientalism" to refer to the phenomenon of stereotyping India characteristic, in her view, of much South Asian diasporic literature that was in essence trying to capitalize on essentalizing cultural differences between the East and the West, 
thus, in a way, re-Orientalizing the Orient. ${ }^{1}$ The fact that literary representations of immigration from the East to the West perpetuate the dichotomous relation between the East and the West is also corroborated by Inderpal Grewal, who in her analysis of Asian immigrant women's narratives penned at the end of the twentieth century claims that in these texts "the female migrant [is] construed through the process of migration as a movement from incarceration within a patriarchal culture [of the East] to freedom within American liberal civil society" (63). Grewal goes on to claim that said narratives are "framed in the binary oppositions between the United States as first world site of freedom and 'Asia' as third world site of repression" (63), and she presents Mukherjee's famous novel Jasmine as an example of such a representation. ${ }^{2}$

Mukherjee's last novel, Miss New India, published in 2011, may be considered a corrective to the view presented above, disregarding for the purposes of this paper the question if such a view is correct with regard to Mukherjee's oeuvre in the first place. ${ }^{3}$ Although Miss New India is set exclusively on the South Asian Subcontinent, first in the town of Gauripur in the north and then in the sprawling southern metropolis of Bangalore, the US is not completely absent in the novel. American influences take the shape of anthropologists or photographers who serve as a source of inspiration for the main character, but also - in a more sinister way — of Bangalore's late-capitalist workplaces outsourced from the US. It is my contention in this paper that through the description of private and (semi)public spaces - the former including residential buildings, the latter coffee shops or offices-Mukherjee shows not only the spatial interconnectedness of the East and the West, which would resist the binary positioning of the two locations in many immigrant texts, but she also indicates the temporal interconnectedness of India's colonial past and the postcolonial, late-capitalist present.

Miss New India may be categorized as an immigrant narrative but of a different kind than that of Mukherjee's well-known novel Jasmine. The two texts

1 In her article "Re-Orientalism: The Perpetration and Development of Orientalism by Orientals," published in 2007, Lau analyzes English-language literary texts authored by South Asian writers, both those based on the Subcontinent and in the diasporas, published between 2002 and 2006. Lau comes to the conclusion that the dominant picture of South Asia is that produced by diasporic writers who are "in a position of power and dominance" (572) vis-à-vis home-based authors and whose diasporic narratives are "insistently setting up South Asia and 'the West' as binaries" (589). The phenomenon of Re-Orientalism is further discussed in a collection of essays that Lisa Lau co-edited with Ana Cristina Mendes, titled Re-Orientalism and South Asian Identity Politics: The Oriental Other Within, published in 2011.

2 Jasmine has been criticized for the alleged perpetuation of such a binary representation of the East and the West also in, among others: Susan Koshy, "The Geography of Female Subjectivity: Ethnicity, Gender, and Diaspora"; Patricia P. Chu, Assimilating Asians: Gendered Strategies of Authorship in Asian America; Anu, Aneja "Jasmine, the Sweet Scent of Exile"; and Gurleen Grewal, "Born Again American: The Immigrant Consciousness in Jasmine."

3 In my view, Mukherjee's narratives offer more complex portrayals of immigration to the West, portrayals that frequently challenge the binary positioning of the East and the West or blame the West for the existence of such polarization; see my book Bicultural Bodies: South Asian American Women's Literature, 40-53 and 116-125. My reading of Mukherjee's texts is similar to that of Asha Sen, who in her analysis of the texts by Bharati Mukherjee, Chitra Banerjee Divakaruni and Jhumpa Lahiri calls for a foregrounding of "the transnational elements within the stories themselves, which complicate their dominant master narratives of assimilation" (57). 
may be read vis-à-vis each other as they both feature young attractive women as protagonists, women whose migratory routes may be different but who nevertheless experience migration in corporeal terms. To put it differently, in both cases migration is a process affecting - and affected by - the protagonists' young attractive female bodies. But while Jasmine travels illegally from India to the US, Anjali Bose-the protagonist of Miss New India - engages in internal migration from the north to the south of the country, fleeing her natal home, where she fell victim to sexual abuse at the hands of the suitor selected by her father, to make her way to Bangalore, a city promising freedom and economic prosperity, even if Anjali's sole marketable assets are her physical attractiveness and her English language skills. Deborah Philips sees Mukherjee's novel as an example of a new genre of narratives of the so-called New India, the term referring to the post-millennial generation that "is asserting itself as aspirational and entrepreneurial, the generation who grew up in the wake of India's second-generation economic reforms and who are now urged to make the most of the opportunities of globalization" (97). According to Philips, the genre was initiated by a popular Indian writer Chetan Bhagat, with female versions of Bhagat's young male characters soon to surface in women writers' attempts at the genre. Although the inclusion of Mukherjee's text within popular narratives that Philips herself dubs "chick lit" may be problematic, the contextualization of Anjali's story within a larger transformation of Indian economy seems valuable. Like the characters in other "New India" narratives, driven by ambition, Anjali moves from a small town to a metropolis in search of career and lifestyle opportunities.

In Bangalore, Anjali is accepted as a boarder at Bagehot house, a dilapidated Raj-era mansion whose proprietress, a mysterious, senile lady by the name of Minnie, boasts of the mansion's glorious past in the following passage of the novel:

\footnotetext{
This is a historically important residence.... In this very room, on these very plates, a very long time ago, His Majesty Edward VII dined, as well as innumerable minor royalty.... We had a retinue of over one hundred, including drivers, gardeners, cooks, butlers, khidmugars, chaprasis, bearers, durwans, and jamadars... The garage in the back housed twenty motor cars-when I say motor cars, I am referring to Bentleys and Duesenbergs, not the rattletraps Indian people drive. My late husband staged durbars for five hundred guests, nizams and maharajas and the viceroy. (116-117)
}

Minnie's own background is not clearly determined but rumor has it that she is a mixed-blood, "the product of the old cantonment culture, the untraceable interaction between an anonymous soldier and a local woman, decades or centuries ago. Minnie was Anglo-Indian" (121). Taking advantage of her looks, she passes for a British lady and continues to dwell in the colonial past, refusing to pay heed of the changes that have occurred and are occurring in contemporary India and the world.

For Anjali, though, and presumably for other boarders before her and now, the house seems "a storage barn, more a warehouse for unusable possessions than an active residence" (112). What another boarder calls "a madhouse" (119) and what Deborah Philips sees as "an image of the transition from the colonial to the global" (101) turns out for Anjali to be a museum of horrors. Anjali discovers that function of 
the house when she breaks one of the rules and ventures inside the forbidden parts of the residence:

\begin{abstract}
She was about to sneak out of all the ballroom when a row of photographs along the far wall drew her attention.... As she drew closer, she began to feel sick. Sariclad bodies lay strewn along a riverbank. The faces were young, no older than she was. Bodies of Sikhs... lay stacked by firewood, and walking among the bodies were uniformed British soldiers, grinning broadly.... Another painting featured a distant row of hanged men, Sikhs with their hair chopped off, hanging by their turbans, silhouetted against the setting sun. Bagehot House was a museum of horrors. (Mukherjee, Miss New India 137)
\end{abstract}

The house's horrors are not of an imaginary nature, though. They are a very real fact of Indian history; the photos draw Anjali's attention to British complicity in the atrocities of the Indian past. Her visit to the museum of horrors, her witnessing of the dead bodies of young Sikhs, thus turns out to be a painful lesson in Indian history, as a result of which Anjali accepts Indianness as part of her identity, while beforehand she mostly viewed herself in ethnic terms - as a Bengali ${ }^{4}$ - rather than in national terms - as an Indian. Anjali's reaction to the peculiar exhibits in this museum of horrors seems to contradict Philips's contention that young Indians are "a generation for whom British colonialism is now an irrelevance" (101). As Mukherjee herself said in an interview, Anjali at that point "comes to an emotional understanding of how her parents' generation has been damaged by colonial injustice and to a stern reassessment of Minnie's British Raj nostalgia. Minnie is no longer foolish and harmless colonial debris; to Anjali, Minnie now becomes the embodiment of colonial evil" ("Globalization and Change" 185). Her snooping around the house leads Anjali to peer beneath the veil of pretense and to formulate very mature conclusions about the nature of historical truth:

Bagehot House was considered a respectable address, a first stop for young working girls. Bagehot House carried its own recommendation. Minnie was admired for running a no-nonsense boarding house that was good training for the corporate world, but there was nothing admirable about it. Anjali, who'd looked on the British period as a long comic opera, felt a sudden connection to all the Indian dead, and the indignities they suffered. She saw her parents still cowering and still recovering from the scars of colonialism and the dazzling new Bangalore as a city of total amnesia. And it was all a lie. (Mukherjee, Miss New India 138-139)

In light of the hideous truth that the Bagehot House hides, it seems only appropriate that the building literally falls apart at the end of the novel as it is plundered and taken to pieces by the dispossessed of postcoloniality and postmodernity, the former untouchables squatting in the mansion's yard, who were incited by ruthless black marketers and who try to salvage whatever can be made profit on. Clearly, the injustices of the past caste system and the injustices of the contemporary late-capitalist world conspire to bring the house to its violent end. ${ }^{5}$

4 As Philips notes, Anjali's surname "Bose indicates that Anjali comes from a Bengali Hindu family and belongs to a caste descended from scribes"; 99, footnote 2 .

5 Mukherjee explained in an interview that it is now a frequent procedure for middlemen to "ease 
Bagehot House, whose depiction in the novel offers a lesson in the intricacies of India's colonial past and post-colonial present, is juxtaposed in the novel with more modern edifices, residential and commercial buildings that are mirror reflections of the architecture of the West, the West being both a source of Bangalore's economic prosperity and a model to aspire to. As the novel puts it, "Bangalore worked off the American clock. Everything about Bangalore - even its time - was virtual" (114). Bangalore is a locus of call-centers outsourced from the US, jobs are thus plentiful for speakers of English. Minnie and her late husband Maxie's comment on the impeccability of Bangalore's geographical location may be read as an ironic prediction of the city's late-capitalist future: "Bangalore was a splendid place, so long as the natives kept their filthy hands off it. Bangalore's weather, a year-round seventy-five degrees, with no bloody monsoon and no mosquitoes, was the clincher. No finer place in the Empire, they agreed, not that an empire in the expansive sense of the word still existed" (122). The Raj era may have ended but India remains interwoven in a complex web of international relations. The colonial system has been substituted with a postcolonial, late-capitalist one, in which the East as a periphery is still heavily affected by the West as the economic center. The people who have chosen Bangalore to be their home are primarily driven by the desire to prosper financially and to live the way the West does: to have apartments similar to those in the US, to use the same amenities, to even drink latte in coffee shop chains modeled on Starbucks. As a result, Bangalore loses its Indian specificity and appears a metropolis that could be situated anywhere in the world.

Mukherjee herself identifies three different kinds of Bangalore's cityscape presented in the novel: what she calls "cantonment" Bangalore, that is the remnants of the city's colonial past, like the Bagehot House analyzed above; the "ultra-modern high-rises" emulating Western architectural styles, luxurious hotels, and educational and medical facilities; and, finally, "Bangalore as a thriving IT-hub" with its industrial parks, shopping malls and eating-out places ("Globalization and Change" 183). The newly-erected residential areas, corresponding to the second type of urban spaces mentioned by Mukherjee, bear in the novel telling names such as Dollar Colony or Reach Colony and seem to be transplants from the architecture of the West:

\begin{abstract}
Reach for the Galaxy, a four-story building with aspirations to luxury, stood between two identical blocks, Reach for the Stars and Reach for the Universe. So that explained the colony's name.... The top floors of all three were still under construction.... The billboard map indicated a yet-to-be-built shopping center and Montessori school: the Bangalore dream, a self-contained, self-sufficient city for the affluent. (179-180)
\end{abstract}

The bland architecture of the new buildings, not rooted in local specificity, may be read as an attempt at homogenizing cultural differences between the East and the West.

The novel also abounds in descriptions of the third type of cityscape mentioned by Mukherjee, parts of which correspond to Marc Augé's definition of non-places. For Augé, non-places function as "the real measure of our time... that could be quantified... by totaling all the air, rail and motorway routes, the mobile cabins called 'means of

aged owners... out of underused, derelict colonial-era estates, like Bagehot House, and sell to real estate developers of high-end investment properties" ("Globalization and Change" 184). 
transport' (aircraft, trains and road vehicles), the airports and railway stations, hotel chains, leisure parks, large retail outlets" (79). Following her perilous journey through a large part of the Indian Subcontinent, Anjali finds herself in a perplexing city, a city whose dialects she fails to understand and whose pace of life mesmerizes her; faced with the havoc of the city, she seeks respite in a Western-style coffee shop:

\begin{abstract}
From the sidewalk she [Anjali] could make out an outdoor coffee bar with patio umbrellas on an elevated plaza between two skyscrapers. A gaggle of voices floated down to her, tinkly voices of hyperconfident breakfasters, chattering in American English. Finally, a language with familiar cadences! She climbed the stairs to the plaza and found herself in a crowded coffee shop. Not just any coffee shop, not another Alps Palace [in Gauripur] with mold blooming on the waterstained walls: this was a Barista. Most of the small round tables were occupied by large groups of noisy patrons her age, dressed, like her, in jeans and T-shirts. Many of the girls were smoking, gesturing wildly, and giggling like schoolgirls. (86-87)
\end{abstract}

Having never been to a coffee shop like that before, Anjali nevertheless feels more at home there than in the streets of Bangalore, and the American English spoken by the employees of the call canters offers a respite from the unfamiliar Southern dialects she hears spoken in the streets. That confirms the coffee shop's status as Augé's non-place, its paradox lying in the fact that "a foreigner lost in a country he does not know (a 'passing stranger') can feel at home there only in the anonymity of motorways, service stations, big stores or hotel chains" (Augé 106).

The description of the coffee shop also serves as an illustration of the fluid subjectivity exhibited by Bangalore's inhabitants working in the call centers who "perform an American identity during their work hours, and then, in their off hours,... discover and act out their individual concepts of self-identity in a rapidly changing India" (Mukherjee, "Globalization and Change" 182). Dressed in Western-style clothes and introducing themselves with Americanized names, these young people epitomize the generation of New India with what Natasha Lavigilante terms in the introduction to her interview with Mukherjee an "'Indo-Western' metropolitan subjectivity" ("Globalization and Change" 178). Working in call centers, which Philips sees as "symbolic of [the current] transition in the Indian economy and workforce - an emblem of an urban and global workforce staffed by educated and ambitious young people" (98), they also experience another facet of supermodernity's non-places, namely "the complex skein of cable and wireless networks that mobilize extraterrestrial space for the purposes of a communication so peculiar that it often puts the individual in contact only with another image of himself or herself" (Augé 79). In this case, the image that these young people transmit is an artificial one: working off the American clock, they pretend to their interlocutors to be Americans based somewhere in the US. In a way, just like the city they inhabit, tellingly called Bang-A-Buck by a newspaper columnist and a character in the novel, they may be said to embody virtual or pretense identities.

The complex web of interconnections of the East and the West depicted in Miss New India raises a question of what effect the change of setting has for Mukherjee's narratives. Many of the novels in Mukherjee's oeuvre are accounts of migration that occurs in the direction from the East to the West, and it is precisely these narratives 
that have been criticized for glorifying the West at the expense of the East. When the direction of migration is changed, as is the case in Mukherjee's astounding novel The Holder of the World - a sort of an alternative version of Nathaniel Hawthorne's The Scarlet Letter and thus an instance of what in the title of their collection Bill Ashcroft et al. termed the empire writing back - the picture gets more complicated and space becomes more resistant to easy polarization. The setting of Miss New India, especially the spatial juxtaposition of the crumbling Raj-era mansion and the sprouting Westernstyle buildings, which is interwoven with the temporal juxtaposition of the colonial period of the Commonwealth and the post-modern flow of capital and ideas, enables Mukherjee to address the pernicious influence that the West continues to exert on the East, which is still constituted as the West's lesser Other.

However, there are some weaknesses or inconsistencies in Mukherjee's portrayal of the interaction between the East and the West. Even if the author is more straightforwardly critical in Miss New India than in her other texts of Western cultural, political and economic hegemony, she still deploys the figures of American or America-returned men who explain India to the protagonist. One of them is Peter Champion, Anjali's teacher and an anthropologist who chronicles disappearing Indian architecture and languages, while the other is a second-generation South Asian American photographer who documents what I would call queer India. The presence of these male, Western/ized figures may be read not only as an instance of mansplaining but also that of whitesplaining, if I may use such an appellation. It is as though the East could not exist without the Western male gaze, which of course harks back to the prevalent conceptualization of Eastern lands in terms of a female body penetrated and conquered by a Western male explorer. The fact that Mukherjee introduces these male, Western/ized characters with almost a sleigh of hand, never problematizing their status in the novel is probably the major weakness of an otherwise complex portrayal of the contact zone- to use Mary Louise Pratt's term - where the East and the West meet, clash, and interact. Mary Louise Pratt defined contact zone as "social spaces where disparate cultures meet, clash, and grapple with each other, often in highly asymmetrical relations of domination and subordination" (4) and "the space in which peoples geographically and historically separated come into contact with each other and establish ongoing relations, usually involving conditions of coercion, radical inequality, and intractable conflict" (6). In the new millennium this contact does not need to occur face to face; rather, it is enabled by state-of-the-art communications technology, which - egalitarian as it may seem-does not, in fact, challenge the existing inequality of the subjects that come into contact with one another in the virtual contact zone. Mukherjee's narrative seems to show that several decades after Edward Said published his seminal work, Orientalism still holds fast to the extent that even Orientals themselves cannot be completely freed from its hold.

\section{Works Cited}

Aneja, Anu. "Jasmine, the Sweet Scent of Exile." Pacific Coast Philology, vol. 28, no.1, 1993, pp. 72-80.

Ashcroft, Bill, Gareth Griffiths, and Helen Tiffin. The Empire Writes Back: Theory and Practice in Post-colonial Literatures. Routledge, 1989. 
Augé, Marc. Non-Places: Introduction to an Anthropology of Supermodernity. Verso, 1995.

Chu, Patricia P. Assimilating Asians: Gendered Strategies of Authorship in Asian America. Duke University Press, 2000.

Grewal, Gurleen. "Born Again American: The Immigrant Consciousness in Jasmine." Bharati Mukherjee: Critical Perspectives, edited by Emmanuel S. Nelson, Garland Publishing, 1993, pp. 181-196.

Grewal, Inderpal. Transnational America: Feminisms, Diasporas, Neoliberalisms. Duke University Press, 2005.

Kimak, Izabella. Bicultural Bodies: South Asian American Women's Literature. Peter Lang, 2013.

Koshy, Susan. "The Geography of Female Subjectivity: Ethnicity, Gender, and Diaspora." Contemporary American Women Writers: Gender, Class, Ethnicity, edited by Lois Parkinson Zamora, Longman, 1998, pp. 138-153.

Lau, Lisa. "Re-Orientalism: The Perpetration and Development of Orientalism by Orientals." Modern Asian Studies, vol. 43, no. 2, 2009, pp. 571-590.

Lau, Lisa and Ana Cristina Mendes, editors. Re-Orientalism and South Asian Identity Politics: The Oriental Other Within. Routledge, 2011.

Mukherjee, Bharati. "Beyond Multiculturalism: Surviving the Nineties." MultiAmerica: Essays on Cultural Wars and Cultural Peace, edited by Ishmael Reed, Viking, 1997, pp. 454-461.

—. "Globalization and Change in India: The Rise of an 'Indian Dream' in Miss New India: An Interview with Bharati Mukherjee." By Natasha Lavigilante. MELUS: Multi-Ethnic Literatures of the U.S., vol. 39, no. 3, 2014, pp. 178194.

_. Miss New India. Mariner Books, 2012.

Philips, Deborah. "The New Miss India: Popular Fiction in Contemporary India." Women: A Cultural Review, vol. 26, nos. 1-2, 2015, pp. 96-111.

Pratt, Mary Louise. Imperial Eyes: Travel Writing and Transculturation. Routledge, 1992.

Said, Edward. Orientalism. Vintage Books, 1979.

Sen, Asha. "From National to Transnational: Three Generations of South Asian American Women Writers." Asiatic, vol. 3, no. 1, 2009, pp. 54-68. 